Diego Sola, El cronista de China.

Barcelona, Universidad de Barcelona, 2018, 320 pp.

ISBN: 9788491680376

\title{
Carlos Ferrer
}

Academia de Artes Escénicas de España james_duty@hotmail.com

$\mathrm{T}$

ierra incógnita, eso era China hasta el s. XVI, pero los comerciantes portugueses pusieron el ojo en el imperio Ming por la preciada pimienta negra y con ellos llegaron algunos escribanos. El dominico Gaspar da Cruz aprovechó la coyuntura comercial portuguesa para documentar su monografía sobre el gigante asiático, difundida en 1577 en el libro del clérigo Bernardino de Escalante Discurso de la navegación que los portugueses hacen a los reinos de Oriente y noticia del Reino de la China. Sin embargo, este libro se vio superado en trascendencia por el que publicó el fraile agustino Juan González de Mendoza (1546-1617) en 1585 sobre dicho reino no cristiano e intitulado Historia de las cosas más notables, ritos y costumbres del Gran Reino de la China. Este volumen era la respuesta al encargo de Felipe II de organizar una embajada destinada al emperador de China y sobre dicho libro y la figura de su autor ha escrito Diego Sola la monografía El cronista de China, publicada por la Universitat de Barcelona en 2018.

Sola escribe, fruto de su tesis doctoral, la biografía de Mendoza y la influencia que tuvo su mencionado libro no solo en España, sino en Europa, con documentación obtenida en archivos de Barcelona, Cambridge, Sevilla y Madrid. El libro de Mendoza, para quien China es el ejemplo "supremo de una civilidad gentil", es la sistematización de una nebulosa de informaciones, una miscelánea de materiales, un retrato de la civilización china mediante informaciones tanto de historia, como de geografía y tradiciones en su primera parte y, en la segunda, un relato de las experiencias del agustino Martín de Rada, Pedro de Alfaro, Martín Ignacio de Loyola entre otros 
en la tierra de la "virtud y la grandeza", tierra que tenía un papel de granero y lujoso mercado. Mendoza no sabía chino, no pisó suelo chino y no pudo recopilar de primera mano los datos, por lo que adolece de profundidad como demuestra Sola. A pesar de ello, el libro de Mendoza, que registró cincuenta ediciones y se tradujo al inglés, francés, alemán e italiano, tuvo un predominio bibliográfico durante tres décadas hasta que Trigault publicó su De christiana expeditione apud sicras al tiempo que se imponían las tesis jesuitas. La difusión del libro mendozano fue extraordinaria y Sola indica que llegaron ejemplares a Quito y que fue leído por Góngora, Barahona de Soto, Montaigne y Francis Bacon.

El profesor Diego Sola interpreta el texto mendozano en su contexto discursivo, explica con claridad el fracaso de la citada embajada y el motivo por el que España desistió de su idea de conquista y la dejó en manos de los jesuitas. El proyecto de la embajada se trabajó entre 1575 y 1581 por empeño de los agustinos de Filipinas y la implicación de Felipe II, y su finalidad era no solo poder comerciar con los productos chinos (seda, porcelana...) sin terceras personas, sino también ampliar el imperio español superando el aislacionismo y la talasofobia de los chinos y orillando las pretensiones portuguesas. Y es que los portugueses ya estaban en Malaca desde $1511 \mathrm{y}$ desde 1556 en Macao, la "puerta de China". El choque de civilizaciones era inevitable, puesto que la pretensión de Felipe II era someter al rey chino por ser su superior, es decir, enviaba una señal de amistad y a la vez de sometimiento, mientras que los chinos se consideraban la única civilización del mundo, a pesar del eurocentrismo imperante. Sola explica el origen del término mandarín y asegura que Felipe II creyó durante un tiempo que con unos miles de soldados, armados con "picas y arcabuces", podría conquistar la opulenta China y que el pueblo se rebelaría contra los tiranos mandarines a las primeras de cambio.

Mendoza, en su libro, "da mayor margen a la vía diplomática, rechazando la tendencia a exagerar la debilidad militar de China por parte de los apologetas de una conquista previa a la evangelización”, según Sola. Por lo tanto, Mendoza únicamente era partidario de conquistar el Celeste Imperio por la vía pacífica de la predicación, una vía que se convertiría en la única posible tras el desastre de la Armada española en 1588.

El agustino llevó a cabo un extenso florilegio de citas latinas de autores clásicos y describió una China sin mendicantes en las calles, bebedora de té, 
con ciudades densamente pobladas, una agricultura extensiva sobre todo de trigo y arroz, la seda como tejido de vestimenta habitual y la condición de sumisas y castas de las mujeres. Mendoza, teólogo consejero de la Curia romana, de personalidad poliédrica capaz de adjudicarse la condición de adalid de la verdad como historiador y luego granjearse la enemistad de los que le rodeaban en Popayán por no ser "pastor sino lobo", erró al pensar que China se autoabastecía de plata, eludió el tema de la homosexualidad y recuperó la definición de China como "paraíso mercantil" de Marco Polo y de Martín de Rada la dispersión de culto y la sofisticación ritual. El propio Mendoza sintetizó su libro al afirmar que "hice un breve compendio, de donde se podía sacar alguna noticia del sitio y descripción de aquellas provincias y fertilidad de ellas, de la Religión, ritos y ceremonias de los moradores, policía con que se gobiernan en paz y orden de milicia con que se sustentan y se defienden de las gentes con que confinan”. Mendoza forjó un relato mundializado sobre el milenario y atractivo Reino del Dragón y se convirtió en su agente. Estamos, en conclusión, ante un libro de lectura interesante y amena, pero no concisa por culpa de algunas reiteraciones, aunque ilustrará de igual modo al lector sin duda alguna. 